\begin{tabular}{|c|c|c|c|c|c|c|c|c|c|c|c|c|c|}
\hline & \multicolumn{2}{|c|}{1957} & \multicolumn{2}{|c|}{1958} & \multirow{2}{*}{1959} & \multirow{2}{*}{1960} & \multirow{2}{*}{1961} & \multirow{2}{*}{1962} & \multirow{2}{*}{1963} & \multirow{2}{*}{1964} & \multirow{2}{*}{1965} & \multirow{2}{*}{1966} & \multirow{2}{*}{1967} \\
\hline & $p$ & $o$ & $p$ & 0 & & & & & & & & & \\
\hline $\begin{array}{l}\text { January } \\
\text { February } \\
\text { March } \\
\text { April } \\
\text { May } \\
\text { June } \\
\text { July } \\
\text { August } \\
\text { September } \\
\text { October } \\
\text { November } \\
\text { December }\end{array}$ & $\begin{array}{l}172 \\
175 \\
182 \\
185 \\
184 \\
188 \\
191 \\
189 \\
191 \\
196 \\
197 \\
197\end{array}$ & $\begin{array}{l}170 \\
172 \\
177 \\
183 \\
187 \\
189 \\
191 \\
190 \\
194 \\
194 \\
197 \\
197\end{array}$ & $\begin{array}{l}196 \\
189 \\
187 \\
180 \\
179 \\
178 \\
176 \\
177 \\
178 \\
174 \\
169 \\
167\end{array}$ & $\begin{array}{l}198 \\
199 \\
203 \\
198 \\
191 \\
189 \\
187 \\
182 \\
183 \\
181 \\
=\end{array}$ & $\begin{array}{l}164 \\
163 \\
168 \\
165 \\
167 \\
163 \\
160 \\
157 \\
153 \\
147 \\
143 \\
140\end{array}$ & $\begin{array}{r}137 \\
136 \\
129 \\
122 \\
117 \\
111 \\
108 \\
106 \\
103 \\
100 \\
97 \\
95\end{array}$ & $\begin{array}{l}93 \\
91 \\
89 \\
87 \\
86 \\
86 \\
87 \\
85 \\
83 \\
81 \\
80 \\
82\end{array}$ & $\begin{array}{l}81 \\
80 \\
79 \\
78 \\
77 \\
76 \\
75 \\
73 \\
71 \\
70 \\
68 \\
64\end{array}$ & $\begin{array}{l}62 \\
61 \\
59 \\
58 \\
57 \\
55 \\
51 \\
52 \\
50 \\
49 \\
48 \\
46\end{array}$ & $\begin{array}{l}46 \\
49 \\
50 \\
47 \\
46 \\
43 \\
40 \\
41 \\
36 \\
33 \\
31 \\
28\end{array}$ & $\begin{array}{l}29 \\
28 \\
23 \\
19 \\
19 \\
16 \\
19 \\
19 \\
16 \\
17 \\
16 \\
15\end{array}$ & $\begin{array}{r}15 \\
14 \\
11 \\
11 \\
9 \\
6 \\
5 \\
2 \\
1 \\
1 \\
0 \\
0\end{array}$ & $\begin{array}{l}0 \\
0 \\
0 \\
0 \\
0 \\
0 \\
0 \\
0 \\
0 \\
0 \\
0 \\
0\end{array}$ \\
\hline
\end{tabular}

of values between the two periods 1749-85 and 1918-54 is most striking.

This fact has been used in our service for ionospheric predictions almost from the beginning of the present cycle; but with the increase in activity marked differences appeared. It was realized, however, that a good fit could be obtained by multiplying figures observed 169 years before by a factor of proportion. Using running means over 13 months and taking July 1784 as a starting date, linked to April 1954, the following equation was obtained in November 1956 :

$$
\bar{x}=1.488 \tilde{y}-12 \cdot 5
$$

where $\bar{y}$ is the value for a particular month of the old cycle and $\bar{x}$ the corresponding value for the present cycle.

In Table 1 predicted sunspot numbers $(p)$, calculated in November 1956 with the above formula, are given for 1957 and 1958 and compared with the available Zurich observational values $(o)$.

The mean square root of deviation between observed and predicted values is $1 \cdot 6$ sunspot, which is very small indeed.

Using the data of April 1954-October 1958, a new equation has been derived for a still better fit :

$$
\vec{x}=1.527 \bar{y}-13.4
$$

Although the change between equation (1) and (2) is very small, this last has been used for the prediction of sunspots as listed in Table 1 from 1959 until the end of the cycle in January 1968. From November 1966 the formula gives negative values; these have been replaced by zeros.

Owing to the very empirical way in which these figures have been derived it is essential to keep a close check with observations as they appear.

However good the relationship between the old and the new cycle has been for the past five years, it does not mean, unfortunately, that it will remain so with certainty in the future.

Without theoretical support, nothing better can be expected for such long-term prediction.

P. Herrinck

Section de Géophysique, Service Météorologique,

Léopoldville, Congo Belge. June 3.

${ }^{1}$ Herrinck, P.. Bull. Acad. Roy. Sci. Col., Nouvelle série, 4 (6).

2Anderson, C. N., J. Geophys. Res., 59, No. 4 (1954).

\section{Anomalous Continuum Radiation from Jupiter}

Followisg the report of Dr. Frank D. Drake ${ }^{1}$, of the National Radio Astronomy Observatory, that Jupiter emits anomalously large amounts of continuum radiation in the vicinity of $21-\mathrm{cm}$. wave- length, observations of Jupiter were undertaken with the Harvard $60-\mathrm{ft}$. radio telescope. With the instrument used as a direct radiometer with a bandwidth of $2 \mathrm{Mc}$ /sec. in the vicinity of $1,420 \mathrm{Mc}$./sec., a signal of amplitude several times the noise fluctuation was found in the expected position of Jupiter on most traces. The averages of at least five right-ascension drift curves were used to obtain the antenna temperatures given in Table 1 . The probable error is less than $0 \cdot 1.5^{\circ} \mathrm{K}$.

\begin{tabular}{|c|c|c|c|c|}
\hline Time (U.T.) & & Date & $\begin{array}{l}\text { No. of curves } \\
\text { averaged }\end{array}$ & $\stackrel{T_{a}}{\left({ }^{\circ} \mathrm{K} .\right)}$ \\
\hline $\begin{array}{l}0203-0403 \\
0408-0608 \\
0613-0817 \\
0451-0711 \\
0209-0543 \\
0548-0747 \\
0139-0604 \\
0130-0420 \\
0140-0713 \\
0319-0616 \\
0302-0727 \\
0157-0423 \\
0428-0707 \\
0105-0439 \\
0444-0733 \\
0313-0502 \\
0133-0448 \\
0452-0721 \\
0048-0430 \\
0434-0718\end{array}$ & $\begin{array}{l}\text { May } \\
,, \\
,, \\
,, \\
,, \\
,, \\
,, \\
,, \\
,, \\
,, \\
,, \\
,, \\
,, \\
,, \\
\text { June } \\
,, \\
,, \\
,\end{array}$ & $\begin{array}{ll}16, & 1959 \\
16 & , \\
16 & ,, \\
18 & ,, \\
20 & ,, \\
27 & ,, \\
21 & ,, \\
22 & ,, \\
23 & ,, \\
25 & ,, \\
26 & , \\
29 & , \\
29 & ,, \\
30 & ,, \\
30 & ,, \\
31 & , \\
1, & 1959 \\
1 & ,, \\
2 & ,, \\
2 & ,,\end{array}$ & $\begin{array}{l}5 \\
5 \\
5 \\
5 \\
5 \\
5 \\
8 \\
7 \\
8 \\
5 \\
9 \\
6 \\
5 \\
7 \\
7 \\
5 \\
5 \\
6 \\
6 \\
7\end{array}$ & $\begin{array}{c}0.51 \\
0.73 \\
0.46 \\
0.86 \\
0.57 \\
0.42 \\
0.75 \\
0.47 \\
0.34 \\
0.46 \\
0 \cdot 31 \\
0.61 \\
<0.16 \\
0.19 \\
0.30 \\
0.28 \\
0.83 \\
0.39 \\
0.64 \\
0.37\end{array}$ \\
\hline
\end{tabular}

Table 1

The results show that the amount of the emission varies with time, by as much as a factor of 2 in a period of a few hours. Attempts are now being made to compare these variations with solar effects and with the low-frequency bursts that are known to come from Jupiter ${ }^{2}$, as well as with periodicities due to Jupiter's rotation.

An antenna temperature of $1^{\circ} \mathrm{K}$. would correspond in our case to a brightness temperature of $6,200^{\circ} \mathrm{K}$. over the surface of Jupiter. This high value, together with the time variations, seems to rule out a thermal origin for this radiation. The calibration of our system has depended on nightly observations of Virgo $A$, the intensity of which at $1,420 \mathrm{Mc}$./sec. is assumed to be the same as that measured recently by Westerhout ${ }^{3}$ at $1,390 \mathrm{Mc} . / \mathrm{sec}$.

Eugene E. Epstein

Harvard College Observatory, Cambridge,

Massachusetts. June 4.

${ }^{1}$ New York Times (May 10, 1959).

2 Carr, T. D., Astro. J., 64, 39 (1959).

${ }^{3}$ Westerhout, G., Bull. Astro. Inst. Neth., 14, 215 (1958). 